\title{
ANALGESIC EFFECT OF BRYOPHYLLUM PINNATUIM L AND CURCUIMA XANTHORRIZA COMBINATION ON MICE'S INDUCED BY FORMALDEHYDE AS ARTHRALGIA AGENT
}

KEY WORDS: arthralgia. Analgetic, Bryophyllum pinnatum L, Curcuma xanthorriza, early phase, late phase

\section{Tuti Sri Suhesti*}

\section{Hanif Nasiatul}

\section{Mustofa}

Department of Pharmacy, Faculty of Health Sciences, Jenderal Soedirman University. *Corresponding Author

Department of Pharmacy, Faculty of Health Sciences, Jenderal Soedirman University.

Faculty of Medical, Jenderal Soedirman University.

Arthralgia is pain in arthritis. Its prevalence is widespread and increasing every year and greatly affect quality of life. Bryophyllum pinnatum L (BP) leaves and Curcuma xanthorriza (CX) rhizomes potensially as antioxidant, analgesic and anti-inflammatory. In this study we examined the analgetic effects of both ethanolic BP and CX extract's combination on the analgetic score using formaldehyde induced. Male mice strain balb/c were divided into 7 groups $(n=7)$, consists of control group (aquadest), aspirin group at a dose of $100 \mathrm{mg} / \mathrm{mL}$, ethanolic extract group with various doses at $200 \mathrm{mg} / \mathrm{kg}$ BB, p.o. Each group was induced by $0.05 \mathrm{ml}$ Formaldehyde (2.5\%) on day. Early phase nociceptive responses were measured in the first 5 minutes and late phase was measured at 15-30 minutes after formaldehyde induced.The analgetic score were determined on early phase and late phase, and then analyzed using ANOVA test. The results showed that the combination of BP and CX extract have analgesic activity in male mice's were induced by formaldehyde. Dose combination of BP and CX with a dose of 100:0 significantly showed optimum analgetic score. The results suggest that BP extract had analgetic activities that should be further examined and potentially candidate as exploited for arthralgia therapies.

\section{INTRODUCTION}

Various types of medicinal plants have been widely used empirically and scientifically researched pharmacological effects. Previous studies have reported that the plant have been shown as anti-inflammatory and analgesic effects that can be used as sole therapy in managing inflammatory conditions or as complementary therapy allowing patients to take smaller doses of conventional anti-inflammatory drugs [1]. The previous investigations that ethanolic extract of leaves of Bryophyllum pinnatum $L$ leaves (BP) and Curcuma xanthorriza (CX) rhizomes extract had the antiinflammatory activity. Arthralgia or joint pain is a degenerative disease due to various disorders of the body, such as bacterial infection, inflammation and muscle spasms. Arthralgia may lead to morbidity, disability, decreased quality of life, and increase the economic burden of patients and their families. Joint pain sufferers worldwide has reached 355 million. This disease is not deadly, but it is quite disturbing and degrade the quality of life and work productivity for the sufferer. Various types of medicinal plants have been widely used and studied empirically pharmacological effects as analgesic agents in the treatment of arthralgia scientifically.

BP leaf and CX rhizomes has been widely used as a traditional medicine. $\boldsymbol{C X}$ is one of the plants that have the potential as an analgesic. Rosli et al. (2012) reported that the BP leaves contain kuercetin, ferulic acid, syringat acid, kumarat acid, sitosterol, bufadienolides-Bryofilin A and hydroxyproline [2]. $B P$ leaf in methanol extract dose of $150 \mathrm{mg} / \mathrm{kg}$ have analgesic activity induced by $50.26 \%$ acetic acid [3]. Morshed et al. (2010) reported that the methanol extract of leaves of K. BP doses of 100, 200 and $400 \mathrm{mg} / \mathrm{kg}$. Anti-inflammatory and analgesic activity in $\boldsymbol{C X}$ leaf allegedly because the compounds contained in it works as an antioxidant [4]. Parveen et al. (2007), suggests that flavonoids suspected antiinflammatory and analgesic activity [5]. The mechanism of action of flavonoids may be related to the activity of the enzyme cyclooxygenase lipooksigenase.

Curcuma rhizomes can be used as a deterrent rheumatic and analgesic. Methanol extract of CX shown to have analgesic activity at 150 and $300 \mathrm{mg} / \mathrm{kg}$ by 33.2 and $50.5 \%$ [6]. Devaraj et al. (2010) reported that the CX doses of 200 and $400 \mathrm{mg} / \mathrm{kg}$ have analgesic activity in rats induced by formaldehyde [7]. Curcumin has anti-inflammatory activity that can reduce the inflammation of the joints [8]. In vitro curcumin has antiinflammatory activity through the inhibition of the pathway immunological extracellular signal-regulated kinase (ERK), which activates the enzyme protein kinase C (PKC) [9] and inhibits the activity of Syk kinase [10]. According Artanti (2009) free ginger essential oil at a dose of $4.89 \mathrm{~g} / \mathrm{kg}$ did not cause toxic symptoms in rats [11]. In a phase 1 clinical trial conducted in 25 subjects with curcumin dose of $8000 \mathrm{mg} /$ day for 3 months, no toxicity effects [12]. Preparations combination of both of these plants can be developed as an analgesic agent in alternative therapies arthralgia so expect their potentiating effect between the two plants. Of this study is expected to obtain scientific data to prove that the combination of $B P$ extract and CX has analgesic activity in a safe arthritis pain in therapy that will strengthen the basis for the use of natural medicine in health care. Many plants have long been recognized as important sources of therapeutically effective medicines. The modern drugs both steroidal and nonsteroidal anti inflammatory drugs are used for the amelioration of the symptoms of the disease, however they offer only temporary relief and also produce severe side effects. The present study aimed to evaluate combination of $B P$ and $C X$ extract in mice model (from the day of arthritis induction and onset, respectively), especially with reference to the anti-inflammatory drug, Aspirin (one of NSAIDs) was used as a reference drug in this study.

\section{RESEARCH METHODS}

\section{Extract Preparation}

Preparation of $B P$ and $C X$ extract obtained by maceration method. Simplicia powder obtained macerated with a ratio of 1:10 ( $1 \mathrm{~g}$ crude drug powder in $10 \mathrm{~L}$ of solvent) using $96 \%$ ethanol as a solvent for 3 days. The powdered of each $B P$ and $C X$ (1000g) were successively extracted with ethanol (70$\left.80^{\circ} \mathrm{C}\right)$.

\section{Analgesic TestWith Stretching Method}

Studies were conducted in male mice strain balb/c weighing 20-30 $\mathrm{g}$ (2-3 month age) obtained from the animal house in the Faculty of Pharmacy, Gadjah Mada University. Animals were acclimatized to experimental conditions in cages and kept under standard environmental conditions $(22 \pm 3 \quad \mathrm{C} ; 12 / 12 \mathrm{~h}$ light/dark cycle). A total of 35 male mice strain balb/c, divided into 7 groups $(n=7)$ and were allowed to feed and water ad libitum. Formaldehyde was used to assess the 
analgetic activity of the combination ethanolic extract of $B P$ and $C X$ in male mice strain balb/c. Animals were randomly divided into seven groups of five animals each. Group I animals received aquadest served as negatif control. Group II, III, IV, V and VI received thats combination ethanolic extract with a dose of $200 \mathrm{mg} / \mathrm{kg}$ BW respectively. Each group received with various combination of compotition of ethanolic extract with 5 dose combination (100-0; 75-25; 5050;25-75; and 0-100).

\section{Observation Of Chemical Stimulation Formaldehyde Methods.}

Pain was induced by injecting $0.05 \mathrm{ml}$ of formaldehyde $(2.5 \%)$ subcutaneously in the back of the sub plantar right foot rat. Test preparation and control is given 30 minutes prior to formaldehyde-induced mice. The time required for the mice licking of the injected leg (licking time) is considered as an indication of pain. Early phase nociceptive responses were measured in the first 5 minutes and late phase was measured at 15-30 minutes after formaldehyde-induced [7]. The amount of inhibition of stretching (\% analgesic) be calculated by formula: 100 - [(P/K) X 100\%)

$\mathrm{P}$ : cumulative amount of stretching on treatment,

$\mathrm{K}$ : the amount of stretching on the control.

\section{Data Analysis}

Data analysis was performed using quantitative analysis. Data nociceptive early phase and late phase obtained from the test analgesic activity by induction of formaldehyde using a combination of extract, The data were expressed and analyzed using the Kolmogorov-Smirnov test to see the distribution of the data. The data are normally distributed then followed by one-way ANOVA with a level of $95 \%$, followed by LSD test to determine differences in the behavior of couples.

\section{RESULTS AND ANALYSIS}

Rendemen of $B P$ and $C X$ of each extract received $9.73 \%$ and $18.179 \%$. Threshold for pain is about the same between one individual to another, but the level of each individual's reaction to pain is very different [13]. Methods of chemical stimuli formaldehyde selected as a test method because this method can assess the response to pain that occurs in the peripheral areas through the early phase and late phase, so that the work can be known specification of a compound having analgesic activity. This method is done by injecting formalin into the plantar surface of the mice on the part of the right rear leg. Paw lick response of mice is a sign of the emergence of pain due to chemical stimuli given has exceeded the threshold of pain and tissue damage caused by the release of compounds called mediators of pain [14].

In this study, test animals were divided into 7 groups: Group I as a negative control, group II-VI were given a combination of $B P$ and $C X$ extract with various composition and group VII as the positive control group were given aspirin $100 \mathrm{mg} / \mathrm{kg}$.

\section{Analgetic Score Test}

The purpose of varying the composition ratio is to find a combination that is effective in producing analgesic activity. Pain response of mice was measured by licking time is the time it takes to lick the legs back right. In the early phase while the late phase after formalin-induced [7].

Table 1. Analgetic Score In Various Treatmen Groups

\begin{tabular}{|l|l|l|l|}
\hline Group & Treatment (n=5) & \multicolumn{2}{|c|}{ \% Analgetic Score } \\
\cline { 3 - 4 } & & Early phase & Late phase \\
\hline I & Negative Control & - & - \\
\hline II & BP : CX (100:0) & 67,03 & 86,61 \\
\hline III & BP : CX (75:25) & 19,23 & 35,04 \\
\hline IV & BP : CX (50:50) & 28,02 & 84,25 \\
\hline V & BP : CX (25:75) & 14,26 & 59,06 \\
\hline VI & BP : CX (0:100) & 24,18 & 47,64 \\
\hline VII & Positive Control & 34,62 & 85,43 \\
\hline
\end{tabular}

www.worldwidejournals.com
The results showed that the combination of $B P$ and $C X$ extract have analgesic activity mice strain Balb/c were induced by formaldehyde. 2.The combination of $B P$ and $C X$ extract with a ratio of 100: 0 to have the optimum analgesic effect in male mice strain Balb/c were induced by formalidehyde.

Pain response of mice was measured by licking time is the time it takes to lick the legs back right. In the early phase, while the late phase after formalin-induced [7]. The results of the cumulative amount of time licking mice are presented in Table 2 and Table 3

Table 2. Total Cumulative Licking Time Ass An Early Phase In The Various Treatment

\begin{tabular}{|l|l|l|l|}
\hline Group & Treatment (n=5) & Mean \pm SD & Specification \\
\hline I & Negative Control & $45.5 \pm 6.245$ & - \\
\hline II & BP : CX $(100: 0)$ & $15 \pm 2.944$ & $\mathrm{a}^{*} \mathrm{~b}^{*}$ \\
\hline III & BP $:$ CX $(75: 25)$ & $36.75 \pm 3.304$ & $\mathrm{a}^{*}$ \\
\hline IV & BP : CX $(50: 50)$ & $32.75 \pm 6.652$ & $\mathrm{a}^{*}$ \\
\hline V & BP : CX $(25: 75)$ & $39 \pm 4.243$ & $\mathrm{~b} *$ \\
\hline VI & BP : CX $(0: 100)$ & $34.5 \pm 7.188$ & $\mathrm{a}^{*} \mathrm{~b}^{*}$ \\
\hline VII & Positive Control & $29.75 \pm 4.992$ & - \\
\hline
\end{tabular}

Table 3. Total Cumulative Licking Time As A Late Phase InThe Various Treatment

\begin{tabular}{|l|l|l|l|}
\hline Group & Treatment (n=5) & Mean \pm SD & Specification \\
\hline I & Negative Control & $63.5 \pm 10.116$ & - \\
\hline II & BP : CX $(100: 0)$ & $8.5 \pm 2.887$ & $\mathrm{a}^{*}$ \\
\hline III & BP : CX $(75: 25)$ & $41.25 \pm 5.909$ & $\mathrm{a}^{*} \mathrm{~b}^{*}$ \\
\hline IV & BP $:$ CX $(50: 50)$ & $10 \pm 4.967$ & $\mathrm{a}^{*}$ \\
\hline V & BP : CX $(25: 75)$ & $26 \pm 4.243$ & $\mathrm{a}^{*} \mathrm{~b}^{*}$ \\
\hline VI & BP : CX $(0: 100)$ & $33.25 \pm 7.932$ & $\mathrm{a}^{*} \mathrm{~b}^{*}$ \\
\hline VII & Positive Control & $9.25 \pm 2.217$ & - \\
\hline
\end{tabular}

\section{Specification}

$a^{*}$ : significantly different from the negative control $\mathrm{b} *$ : significantly different from the positive control (LSD test. $P>0.05$ )

Treatment group early phase and late phase were given a combination of $B P$ and $C X$ with a ratio of 100:0 at a dose of 200 $\mathrm{mg} / \mathrm{kg}$ had a smallest cumulative amount of time licking. This suggests that a single duck bill leaf extract can provide a better analgesic effect than ginger rhizome extract alone or combination with BP extract of ginger rhizome. The number of cumulative licking time tested normality using the Kolmogorov-Smirnov method. The results of the KolmogorovSmirnov normality test showed that the data were normally distributed. It is based on the significant value in each group is greater than 0.05 ( $\mathrm{sig}>0.05$ ). Data were statistically analyzed using analysis of variance (ANOVA) unidirectional pattern with a level of $95 \%$. Analysis of variance was used to look at differences in analgesic effect of all treatment groups.

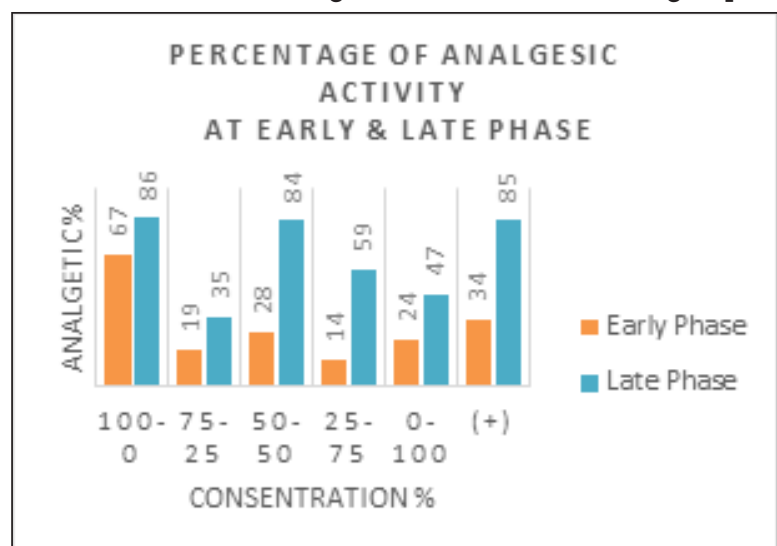

Figure 1. Percentage Of Analgesic Generated Mice

Then followed by LSD test analysis to determine differences 
in the behavior of couples with the provision that if $p>0.05$ means not found significant differences between the control and treatment groups. whereas if $\mathrm{p}<0.05$ then there is a significant difference between the control and treatment groups. The results showed that the group of early phase group II. III. IV. VI has a significant difference to the negative control group and group II. V. VI showed a significant difference to the positive control group. While the late phase showed that all treatment groups had a significant difference to the negative control group. and group III. V. VI has a significant difference to the positive control group. Test results of ANOVA and LSD analysis shown in appendix 3 From the data of cumulative licking time generated mice in each treatment group. hereinafter specified percentage of analgesic activity by using equation Handeson-Forsaith presented in the form of a bar chart in Figure 1.

The measurement results showed that the percentage of activity analgesic group II were given a combination of duck with ginger extract with a ratio of 100: 0 to have the greatest analgesic activity. The greater the activity. the analgesic effectiveness of the resulting extract the better. Of image data 4.1 and Table 4.2 show an increase in paw lick protection in the treatment group were given a single duck bill leaf extract. An extract which has analgesic showed that the extract can inhibit the response induced paw lick chemical stimulation in the form of $2.5 \%$ formalin. Based on the above data. when compared to the positive control. the greatest analgesic effect was obtained in group II with leaf extract single duck bill with the percentage of analgesic activity in the early phase and late phase respectively of $67.033 \%$ and $86.614 \%$. According to Turner (1965). that are considered effective analgesic activity pharmacologically indicated if the percentage is more than 50\% [15]. then the group which meets these requirements in an early phase is a group II and the late phase is a group II. IV. and V. The higher the analgesic activity an extract. the higher the ability of the extracts to inhibit the response to paw lick. If the response can be inhibited the paw lick licking time generated would be even smaller. It is possible that the magnitude of the inhibition of pain response due to the many levels of flavonoids contained in the extract. Duck bill contains flavonoids that can work as an antiinflammatory and analgesic. Flavonoids have an analgesic effect by inhibiting the enzyme cyclooxygenase which is the first step the formation of prostaglandins [16]. So the duck bill can work optimally in the workplace peripheral. Flavonoids also have antioxidant capabilities that can capture reactive oxygen and peroxyl radicals. and then neutralizing it. inhibiting the oxidation of arachidonic acid into endoperoksida and lowered enzyme activity lipooksigenase [17]. Inhibition of the formation of endoperoksida cause the formation of prostaglandins that can trigger pain.

\section{CONCLUSION}

The results showed that the combination of Bryophyllum pinnatum $L$ leaves and Curcuma xanthorriza rhizomes extract have analgesic activity mice strain $\mathrm{Balb} / \mathrm{c}$ were induced by formaldehyde. Dose combination of $B P$ and $C X$ with a dose of 100:0 significantly resulted optimum analgetic score. The results suggest that $B$. pinnatum extract had analgetic activities that should be further examined and potentially candidate as exploited for arthralgia therapies.

\section{REFERENCES}

[1] Nayak. S.B.. Marshal. J.R.. Isitor. G.. Wound Healing potential of ethanolic extract of Kalanchoe pinnata Lam Leaf- A preliminary study. Indian Journal of Experimental Biology.48:572-576.2010.

[2] Rosli. NHM.. Salleh. S.K.. Omar. Z..Draman. SFS. Tajuddin. NA... Determination of Quercetin in Local Kalanchoe Pinnata Extract Using High Performance Liquid Chromatography. Proceeding UMT 11 th International Annual Symposium on Sustainability Science and Management 09th - 11th July 2012. Terengganu. Malaysia. 2012.

[3] Putranti. Z.D.. Baroroh. H.N.. Arjadi. F.. Aktivitas Analgetik Ekstrak Metanol Daun Sosor Bebek (Kalanchoe pinnata Pers.) Pada mencit yang diinduksi asam asetat.Media Farmasi Indonesia. 2 (6).2011.

[4] Morshed.A.. Hossain. H.. Shakil. S.. Nahar.K.. Rahman.S.. Ferdausi. D.. Hossain.T.. Ahmad.I.. Chowdhury. M.H.. Rahmatullah. M. Evaluation of
Antinociceptive Activity of two Bangladeshi Medicinal Plants. Kalanchoe pinnata (Lam.) Pers. and Lagerstroemia speciosa (L.) Pers. Advances in Natural and Applied Sciences. 4(2): 193-197.2010.

[5] Parveen. Z.. Yulin D.. Muhammad K.S.. Rongji D.. Waqar A.. Yu H.Y Antiinflamatory And Analgesic Activities of Thesium chinense Turcz Extracts and its Major Flavanoids. Kaempferol and Kaempferol-3-O-glucoside. http://www.jstage.jst.go.jp. diakses 22 April 2013.2007.

[6] Mahmood.M.K.H..Bachar.S.C.. Islam. M.D.S. Ali.M.S.. Analgesic and Diuretic Activity of CX.Dhaka Univ.J.Pharm.Sci..3:1-2.2004.

[7] Devaraj. S.. Esfahani. A.S.. Ismail. S.. Ismail. S.. Ramanathan. S.. Evaluation of the Antinociceptive Activity and Acute Oral Toxicity of Standardized Ethanolic Extract of the Rhizome of CX Roxb.Molecules (15):2925-2934.2010.

[8] Zahidah. A.F.. Faizah. O.. Aqilah. K.N.. Tatyanna. K. Curcumin as Anti Arthritic Agent in Collagen Induced Arthritic Sprague Dewley. Sains Malaysiana. 4 1(5): 591-59..2012.

[9] Baek. O.S.. Kang. O.H.. Choi.Y.A.. Choi. S.C.. Kim. T.H.. Nah. Y.H.. Kwon. D.Y. Kim. Y.K.. Kim. Y.H.. Bae. K.H.. Lim. J.P. and Lee. Y.M.. Curcumin Inhibits Protease-activated Receptor-2 and -4-mediated Mast cell Activation. Clin Chim Acta. (338). 1-2.2003.

[10] Lee. J.H.. Kim. J.W.. Ko. N.Y.. Mun. S.H.. Her. E.. Kim. B.K.. Han. J.W.. Lee. H.Y. Beaven. M.A. and Kim.Y.M.. Curcumin. a constituent of curry. suppresses IgEmediated allergic response and mast cell activation at the level of Syk . $J$ Allergy Clin Immunol. 121(5). 1225-31.2008.

[11] Biswas. S.K.. Chowdury. A.. Das. J.. Hosen. S.M.Z.. Uddin. R.. dan Rahaman. S. Literature review on pharmacological potentials of Kalanchoe pinnata (Crassulaceae). African Journal of Pharmacy and Pharmacology. 5(10): 12581262.2011 .

[12] Chainani-Wu. N.. Safety and Anti-Inflammatory Activity of Curcumin: A Component of Tumeric (Curcuma longa). J Altern Comp Med.. 9 (1). 161-168. 2003.

[13] Matthew.S..Jain.A.K..James. M...Matthew. C.. dan Bhowmik.D..Analgesic And AntiInflammatory Activity of Kalanchoe Pinnata (Lam.) Pers. Journal of Medicinal Plants Studies. 1(2):24-28.2013.

[14] Woolf. C.J.. Pain moving from symptom control toward mechanism spesific pharmacologic management. Annals of Internal Medicine. 140(6): 441-451. 2004

[15] Turner. R.A.. Screening Methods in Pharmacology. 69-117. Academic Press. NewYork \& London. 1965.

[16] Tanko. Y.. Mohammed. A.. Saleh. M.I.A.. Etta. E.. Bako. I.G.. dan Yerima. M. Antinociceptive and Anti-Inflammatory Activities of Ethanol Extract of Bryophyllum Pinnatum Laboratory Animals. IOSR Journal of Dental and Medical Sciences. 3(1):46-49.2013.

[17] Ozaki. Y.. Antiinflammatory effect of $C X$ Roxb and its active principles. Chemical Pharmaceutical Bulletin.38(4): 1045-1048.1990. 